\title{
Arbuscular mycorrhizal fungi and indolebutyric acid alter rooting rate and physiological characteristics of Lantana camara L. (Verbenaceae)?
}

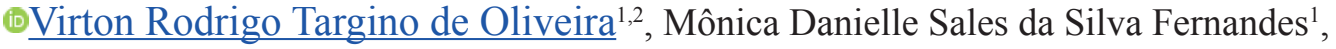 \\ Cynthia Cavalcanti de Albuquerque ${ }^{1}$ and Francisco Fábio Mesquita Oliveira ${ }^{1}$
}

Received: 13.12.2017; accepted: 11.07.2018

\begin{abstract}
Arbuscular mycorrhizal fungi and Indolebutyric acid alter the rooting rate and physiological characters of Lantana camara? L. (Verbenaceae)). The objective of this study was to evaluate the rooting and some physiological characteristics of Lantana camara L. (Verbenaceae) stakes in different concentrations of indolebutyric acid (IBA) and its association with the arbuscular mycorrhizal fungi (AMF) Claroideoglomus etunicatum (W.N. Becker \& Gerd.) C. Walker \& A. Schüssler e Gigaspora albida N.C. Schenck \& G.S. Sm. The experimental design was completely randomized in a $3 \times 3$ factorial scheme with three replicates, where the first factor was the AMF and the second factor by doses of IBA $(0 ; 1.0$ and $\left.1.5 \mathrm{mg} \cdot \mathrm{mL}^{-1}\right)$. The results showed that the presence of AMF in the substrate, as well as the IBA, isolated or in association stimulates the rooting and some physiological characters of $L$. camara cuttings.
\end{abstract}

Keywords: cuttings, IBA, mycorrhiza, phytoregulator, vegetative propagation

RESUMO - (Fungos micorrízicos arbusculares e ácido indolbutírico alteram a taxa de enraizamento e caracteres fisiológicos de Lantana camara? L. (Verbenaceae)). O estudo teve como objetivo avaliar o enraizamento e alguns caracteres fisiológicos em estacas de Lantana camara L. (Verbenaceae) em diferentes concentrações de ácido indolbutírico (AIB) e sua associação com os fungos micorrízicos arbusculares (FMA) Claroideoglomus etunicatum (W.N. Becker \& Gerd.) C. Walker \& A. Schüssler e Gigaspora albida N.C. Schenck \& G.S. Sm. Utilizou-se o delineamento experimental inteiramente casualizado em esquema fatorial $3 \times 3 \mathrm{com}$ três repetições, sendo o primeiro fator composto pelos FMA e o segundo fator pelas doses de AIB $\left(0 ; 1,0\right.$ e $\left.1,5 \mathrm{mg} \cdot \mathrm{mL}^{-1}\right)$. Os resultados mostraram que a presença de FMA no substrato, assim como o AIB, isolados ou de forma interativa estimulam o enraizamento e alguns caracteres fisiológicos de estacas de L. camara.

Palavras-chave: AIB, estaquia, fitorregulador, micorrizas, propagação vegetativa

\section{Introduction}

Lantana camara L. (Verbenaceae) sensu stricto is a woody shrub native to America, specifically from Mexico, the United States, Jamaica and Brazil (Sanders 1987), although the genus has a pantropical distribution with some species from Africa and India (Day et al. 2003). The species generally dominates understory vegetation in disturbed areas, often forming dense monospecific vegetation, being highly invasive, occupying a large percentage of vegetation cover in regions where it is considered exotic (Kirimuhuzya et al. 2009). In these areas, L. camara represents a threat to biodiversity, due to its rapid growth (Day et al.
2003) and its produced allelochemicals (Gantayet et al. 2014).

The wide and diverse distribution of L. camara is a reflection of its broad ecological tolerances (Priyanka \& Joshi 2013), favoring its use for the most varied purposes, working as firewood and hence material (Jimenez-Arellanes et al. 2003), along with its relevant use in medicine. The species has antimicrobial activity against Staphylococcus aureus, Proteus vulgaris, Pseudomonas aeruginosa, Viaco cholerae, Escherichia coli and two multiresistant strains of E. coli and S. aureus (Barreto et al. 2010); anti-filarial (Misra et al. 2006), anti-inflammatory (Gidwani et al. 2009), anticancer and antiproliferative activities (Ghosh \&

1. Universidade do Estado do Rio Grande do Norte, Departamento de Ciências Biológicas, Rua Professor Antônio Campos, s/n, BR 110, Km 48, Bairro Costa e Silva, 59600-000, Mossoró, Rio Grande do Norte, Brasil

2. Corresponding Author: virtonrodrigo@gmail.com 
Das Sarma 2010). This therapeutic diversity is due to the presence of essential oils, phenolic compounds, flavonoids, alkaloids, glycosides, saponins, triterpenes and sesquiterpenoids (Venkatachalam et al. 2011, Kensa 2011, Kalita et al. 2011, Bhakta \& Ganjewala 2009).

In the semi-arid region of Brazil's Northeast, where the species is used as an ornamental and floral resource by bees (Aguiar \& Zanella 2005), the use of its essential oil in applied research has developed significantly (Coitinho et al. 2006; Costa et al. 2009), demanding a great quantity of raw material. Due to L. camara deciduosity, studying its production in controlled environments is necessary, regardless of the period of the year. Its propagation usually occurs by sexual reproduction, and the seeds are able to germinate at any time of the year, if there is sufficient soil moisture and light, and ideal temperature for emergence and development of the embryo (Duggin \& Gentle 1998). However, seed germination rate in $L$. camara is considered low (4-45\%) due to dormancy, low viability and meiotic instability (Sahu \& Panda 1998), thus justifying the vegetative propagation that can replace the sexual reproduction (Raizada \& Raghubanshi 2010).

Vegetative propagation, especially cutting, is a very common practice. In this process, rooting of cuttings depends on a series of factors, such as the type of cutting, nutritional conditions, irrigation, moisture, endogenous rooting promoters (Hartman et al. 2002). For some species, the percentage of cuttings that produce roots can be a limiting factor for the production, since the success of the plants in the environment depends on their capacity to produce roots in large quantities, with longer length and, consequently, seedlings with greater vigor (Washa et al. 2012).

The application of plant growth regulators, such as auxins, promotes adventitious root formation and stem growth (Haissig \& Davis 1994), and the combination of these substances with arbuscular mycorrhizal fungi (AMF) contributes to increase the percentage of rooting of cuttings (Scagel \& Linderman 1998) (Scagel \& Linderman 1998). AMFs are the most prevalent type of fungal root symbionts, ecologically vital, and essential for the growth, development and survival of various plant species (Lone et al. 2015). AMFs are extremely important for the improvement of soil quality through its beneficial effects on host plant physiology and ecological interactions, therefore improving soil moisture and physicochemical properties (Augé et al. 2001). The symbiotic association with AMF promotes faster and larger plant growth through greater efficiency in the uptake and translocation of macro and micronutrients, also increasing plant resistance to biotic and abiotic stresses, and interacting synergistically with plant growth (Ning \& Cumming 2001, Watts-Williams et al. 2014).

Following the above, this study aimed to evaluate the effect of different concentrations of indolebutyric acid (IBA) and its use in conjunction with Claroideoglomus etunicatum (W.N. Becker \& Gerd.) C. Walker \& A. Schüssler and Gigaspora albida N.C. Schenck \& G.S. Sm, on the rooting of $L$. camara cuttings.

\section{Material and methods}

The work was executed in the State University of Rio Grande do Norte, located on the Municipality of Mossoro ( $5^{\circ} 12^{\prime} 18,25^{\prime}$ " South, 37 $18^{\prime} 53,10^{\prime \prime}$ West). The typical climate of this region registers average temperatures around $27.2^{\circ} \mathrm{C}$. According to the Köppen climate classification, the área presents a climate defined as BSwh (hot semiarid/steppe climate), with a rainy season in summer, which delays in autumn (possibly being absent during this period), and annual rainfall usually less than $750 \mathrm{~mm}$ (Carvalho 2017). The experiment was conducted in a greenhouse covered with $125 \mu \mathrm{m}$ light diffuser polyethylene film, and the cuttings were grown in polyethylene containers having $5 \mathrm{~kg}$ of substrate composed of soil from the area where the cuttings were collected and sand, at the ratio of $1: 1(\mathrm{v} / \mathrm{v})$. The substrate was properly sterilized in a vertical autoclave for the removal of undesired microorganisms, and 500 grams of soil with C. etunicatum or G. albida inoculum were added to the soil, except for the control group (not inoculated).

The plant material was collected from adult plants at a place of its natural occurrence of in the municipality of Mossoró, in a coordinate area $5^{\circ} 12^{\prime} 16.08^{\prime}$ "South and $37^{\circ} 18^{\prime} 56.61$ " West, with its leaves and branches removed for the preparation of the cuttings, which were immersed in water up to half its length for a period of 24 hours, and then randomly distributed to compose the treatments. The bases of the cuttings underwent rapid 1 minute immersion in solution containing IBA in the concentrations of $1.0 \mathrm{mg} \cdot \mathrm{mL}^{-1}$ or $1.5 \mathrm{mg} \cdot \mathrm{mL}^{-1}$, being the control group immersed only in water. 
Manual irrigations were realized twice a day, with the volume of water used according to the pot capacity, adding a leaching fraction of $20 \%$ for irrigation solutions to percolate in order to avoid excessive salt accumulation. The nutrient conditions of the substrate were maintained by application, at eight-day intervals, of nutrient solution (Hoagland \& Arnon 1950), throughout the cycle.

After 40 days of striking, the percentage of cuttings sprouts, number of shoots per cuttings, height of plants, rooting percentage, root length and total dry matter (TDM) were quantified. Moreover, the leaf relative water content (RWC) and photosynthetic pigments were also quantified.

For the quantification of the photosynthetic pigments, fresh tissue samples were collected, stored in paper bags, packaged in a Styrofoam box with ice and transported to the laboratory. Leaf disks of $1.1 \mathrm{~cm}$ in diameter were then weighed and macerated by a mortar and pestle using $10 \mathrm{~mL}$ of $80 \%(\mathrm{v} / \mathrm{v})$ cold acetone, plus $0.1 \%(\mathrm{~m} / \mathrm{v})$ magnesium carbonate. The extracts were transferred to test tubes and centrifuged at $2500 \mathrm{rpm}$ for 5 minutes. Finally, the absorbance readings (A) of the samples were measured in a UVvisible spectrophotometer, at wavelengths of 645 , $663 \mathrm{~nm}$ for chlorophylls and $470 \mathrm{~nm}$ for carotenoids. From the data of absorbances and dilution factors (FD), the levels of chlorophyll $a\left(\mathrm{C}_{\text {chla }}\right), b\left(\mathrm{C}_{\text {chlb }}\right)$ and total carotenoids (xanthophylls + carotenes; $x+c$ ) (Lichtenthaler 1987) were quantified. The results were expressed in microgram per gram of fresh leaf tissue mass ( $\left.\mu \mathrm{g} \mathrm{g}^{-1} \mathrm{LM}\right)$, using the following equations:

$$
\begin{gathered}
\mathrm{C}_{\mathrm{a}}\left(\mu \mathrm{g} \mathrm{g}^{-1} \mathrm{MF}\right)=\left[12,21 \mathrm{~A}_{663 \mathrm{~nm}}-2,81 \mathrm{~A}_{646 \mathrm{~nm}}\right] \times \mathrm{FD} \\
\mathrm{C}_{\mathrm{b}}\left(\mu \mathrm{g} \mathrm{g}^{-1} \mathrm{MF}\right)=\left[20,13 \mathrm{~A}_{646 \mathrm{~nm}}-5,03 \mathrm{~A}_{663 \mathrm{~nm}}\right] \times \mathrm{FD} \\
\mathrm{C}_{\mathrm{x}+\mathrm{c}}\left(\mu \mathrm{g} \mathrm{g}^{-1} \mathrm{MF}\right)=\frac{1000 \mathrm{~A}_{470 \mathrm{~nm}}-3,27 \mathrm{C}_{\mathrm{a}}\left(\mu \mathrm{g} \mathrm{mL}^{-1}\right)-104 \mathrm{C}_{\mathrm{b}}\left(\mu \mathrm{gL}^{-1}\right)}{198} \times \mathrm{FD}
\end{gathered}
$$

The relative water content of $L$. camara leaves was determined according to the methodology proposed by Barrs \& Weatherley (1962), where six leaf discs were extracted, and the fresh tissue mass $\left(\mathrm{M}_{\mathrm{f}}\right)$ of the disks was determined in analytical balance. The mass of the turgid tissue $\left(M_{t}\right)$ was obtained after the rehydration of the disks in deionized water for $24 \mathrm{~h}$. To do so, the excess water was removed using filter paper. Dry tissue mass $\left(\mathrm{M}_{\mathrm{d}}\right)$ was obtained after the discs were dried for $48 \mathrm{~h}$ at $70{ }^{\circ} \mathrm{C}$ in a forced air circulation oven. The RWC was calculated using the following equation:

$$
\operatorname{TRA}(\%)=\frac{\left(\mathrm{P}_{\mathrm{f}}-\mathrm{P}_{\mathrm{s}}\right)}{\left(\mathrm{P}_{\mathrm{t}}-\mathrm{P}_{\mathrm{s}}\right)} \times 100
$$

The data were analyzed using a completely randomized design, with 3 replicates (each replicate corresponded to 1 pot containing 3 cuttings), in a $3 \times 3$ factorial scheme, involving three qualitative factors and three quantitative factors (AMF versus IBA concentrations). The data were submitted to the Lilliefors normality test and two-way ANOVA for all variables, followed by the Scott-Knott test, which was performed to detect significant differences $(\mathrm{p} \leq 0.05)$ through ASSISTAT ${ }^{\circledR}$ software, version 7.6 beta (Silva 2015).

\section{Results}

The presence of AMF in the substrate, as well as IBA, isolated or acting interactively, affected the percentage of sprouted cuttings (figure $1 \mathrm{~A}$ ), number of sprouts per cuttings (figure 1 B), plant height (figure $1 \mathrm{C}$ ), rooting percentage (figure $1 \mathrm{D}$ ), root length (figure $1 \mathrm{E}$ ) and total dry matter (figure $1 \mathrm{~F}$ ). The tests also affected the percentage of chlorophyll "a", but not chlorophyll " $b$ " and carotenoids percentages (figure 2).

The analysis of variance for the percentage of rooted cuttings, showed significance of the hormonal factors $\left(\mathrm{F}_{2,18}=3,8745 ; \mathrm{p}<0,0398\right)$ and AMF $\left(\mathrm{F}_{2,18}=3,8739 ; \mathrm{p}=0,0398\right)$, being the IBA versus AMF interaction also significant $\left(\mathrm{F}_{4,18}=7,9993 ; \mathrm{p}=\right.$ 0,0006 ) (figure $1 \mathrm{~A}$ ). The cuttings treated without AMF (control), without IBA, and with only IBA at the concentration of $1 \mathrm{mg} \cdot \mathrm{mL}^{-1}$, along with the ones treated with AMF and $1 \mathrm{mg} \cdot \mathrm{mL}^{-1}$ IBA showed the highest sprouting percentages (figure $1 \mathrm{~A}$ ). Moreover, for the number of shoots per cuttings, the hormonal factors $\left(\mathrm{F}_{2,18}=3,6362 ; \mathrm{p}=0,0471\right)$ and $\mathrm{AMF}$ $\left(\mathrm{F}_{2,18}=8,4160 ; \mathrm{p}=0.0026\right)$ were significant, as well as in the IBA versus AMF interaction $\left(\mathrm{F}_{4,18}=3.3855\right.$; $\mathrm{p}=0.0312$ ) (figure $1 \mathrm{~B}$ ). The height of the plants was significantly influenced by the hormonal factor 


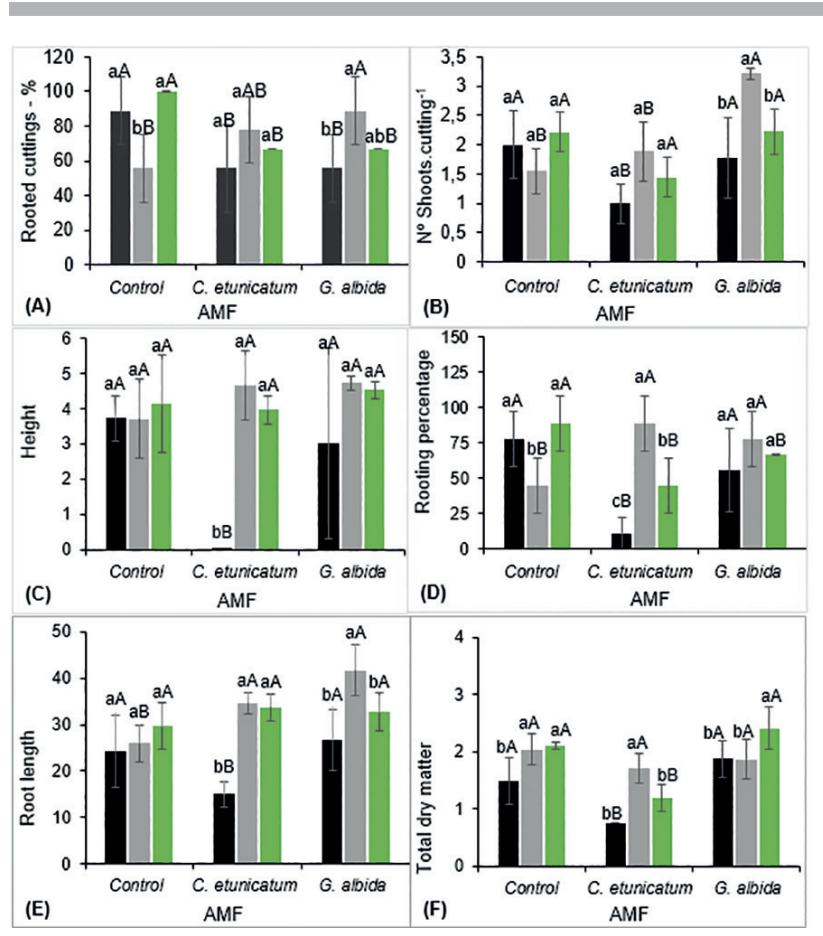

Figure 1. Rooted cuttings percentage (A), number of shoots.cutting$1(B)$, height $(C)$, rooting percentage (D), root length (E) and total dry matter $(\mathrm{F})$ of $L$. camara obtained by the application of $1 \mathrm{mg}$. $\mathrm{mL}^{-1}$ (central column) and $1.5 \mathrm{mg} \cdot \mathrm{mL}^{-1}$ (right column) IBA, or without the application (left column), and in the presence of AMF. Means followed by the same letter, lowercase for IBA and upper case for AMF, do not differ statistically from one another by the Scott-Knott (HSD) test ( $\mathrm{p}<$ $0.05, n=3)$. The bars represent standard deviation of the mean.

$\left(\mathrm{F}_{2,18}=9,4038, \mathrm{p}=0.0015\right)$ and the IBA versus AMF interaction $\left(\mathrm{F}_{4,18}=3.44 ; \mathrm{p}=0.0295\right)$, although AMF did not present significant effect on this variable $\left(\mathrm{F}_{218}=2.7733, \mathrm{p}=0.0891\right)$ (figure $\left.1 \mathrm{C}\right)$. Summarizing, only the concentration of $0 \mathrm{mg} \cdot \mathrm{mL}^{-1}$ (control) associated with $C$. etnicatum was inferior, comparing to the other treatments (statistically similar), suggesting that the use of IBA is required for significant results if $L$. camara is inoculated by this fungus.

The treatments with IBA $\left(\mathrm{F}_{2,18}=3.8745\right.$, $\mathrm{p}=0.0398)$ and $\operatorname{AMF}\left(\mathrm{F}_{2,18}=3,8739 ; \mathrm{p}=0,0398\right)$, as well as the interaction between both $\left(\mathrm{F}_{4,18}=7,9993 ; \mathrm{p}=\right.$ $0,0006)$, affected significantly the percentage of rooted cuttings, with the control (without AMF), IBA at 1.5 $\mathrm{mg} . \mathrm{mL}^{-1}$, and the treatments with C. etunicatum. and $G$. albida and IBA at $1 \mathrm{mg} \cdot \mathrm{mL}^{-1}$ having more expressive results (figure $1 \mathrm{D}$ ). Similarly, the roots length was also affected by the IBA $\left(\mathrm{F}_{2,18}=15,7092 ; \mathrm{p}<0,0001\right)$, the $\operatorname{AMF}\left(\mathrm{F}_{2,18}=5,1695 ; \mathrm{p}=0,0168\right)$ and interaction between both $\left(\mathrm{F}_{4.18}=3,9565 ; \mathrm{p}<0,01786\right.$ ) (figure $1 \mathrm{E}$ ), which the rooted cuttings with IBA at $1 \mathrm{mg} \cdot \mathrm{mL}^{-1}$ and G. albida had the largest length. These results, when analyzed together with the TDM, show that the use of IBA and AMF in L. camara cuttings is important

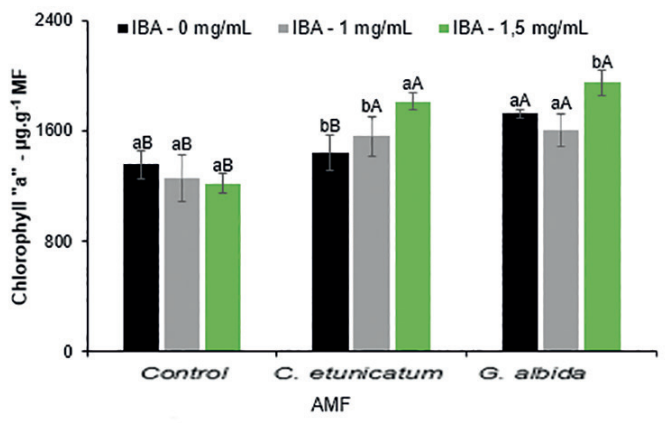

Figure 2. Concentrations of chlorophyll "a" in L. camara plants from IBA application cuttings, in the presence of two AMF soles. Means followed by same letters, lowercase for IBA and upper case for AMF, do not differ statistically from one another by the Scott-Knott test $(\mathrm{p}<0.05, \mathrm{n}=3)$. The bars represent the standard deviation of the mean.

for its growth, since these factors, combined and isolated, presented significance. (IBA: $\mathrm{F}_{2,18}=9,8958$; $\mathrm{p}=0,0012)\left(\right.$ AMF: $\left.\mathrm{F}_{2,18}=21,1908 ; \mathrm{p}<0,0001\right)$ (Both: $\mathrm{F}_{4,18}=3,2163 ; \mathrm{p}=0,037$ ) (figure $1 \mathrm{~F}$ ).

The chlorophyll "a" concentration $\left(\mathrm{C}_{\text {chla }}\right)$ was influenced by the use of IBA $\left(\mathrm{F}_{2,18}=4.2913\right.$; $\mathrm{p}<0.0299)$, AMF $\left(\mathrm{F}_{2,18}=31,1615 ; \mathrm{p}=0,0001\right)$, and both factors $\left(\mathrm{F}_{4,18}=3,5258 ; \mathrm{p}=0,0271\right)$ (figure 2).

The effects of IBA and AMF interaction were highly significant on chlorophyll "a" content, and the highest values derived from the treatments with the biggest IBA dose and the inoculation of $C$. etunicatum and G. albida (1814,168 $\mu$ g.g-1 LM and $1948,889 \mu \mathrm{g} \cdot \mathrm{g}^{-1} \mathrm{LM}$, respectively), when compared to treatments without AMF.

Regarding chlorophyll "b" content, carotenoids and relative water content were not significant on the tested, isolated and/or combined factors $(\mathrm{p}>0.05)$.

\section{Discussion}

The results showed that $L$. camara cuttings, when inoculated with mycorrhizal fungi in the presence of IBA, had a considerable increase in their biometric characteristics, although in some cases there was no difference in comparison to the control. Studies with Prumus persica and Citrange carriz showed that the association between AMF and IBA is responsible for a large increase in vegetative development, and when analyzed separately, they do not present good results, with IBA being ineffective when not associated (Souza et al. 2000, Nunes et al. 2010). 
The winged-stem passion flower (Passiflora alata), inoculated with G. albida, shows bigger height and biomass production, having better development whenever its seedlings are associated with AMF (Silva et al. 2004). Similarly, roots of sweetsop (Annona squamosa) cuttings develop well in symbiosis with this fungus, increasing its biomass production (Coelho et al. 2012). The IBA can increase linearly the rooting percentage in small cuttings (Faganello et al. 2015), thus being the isolated effect of both fungi and the advantageous hormone in the rooting promotion. Pio and collaborators (2005) obtained similar results when studying the rhizogenesis in olive cuttings (Olea europaea) and found that there was interaction between IBA concentrations and number of leaves for root system variables (rooted cutting percentage, number of roots originated from cuttings and average length of the roots).

Although the content of carotenoids and chlorophyll "b" had not been altered by the analyzed factors, the results indicated that the symbiosis between AMF and L. camara cuttings expressively the concentration of chlorophyll "a", reflecting a higher photosynthetic rate required by the high carbon demand demanded by the association between the plant and AMF (Rahmawati et al. 2014).

The increase in chlorophyll content assists in the better overall performance of fungi associated plants, and it can be concluded that AMF inoculation may represent a valid instrument, along with the addition of IBA for the rooting of $L$. camara cuttings on short term, as developed in this work, and its positive effects manifest more intensely during the development of the studied species. Moreover, it is suggested that mycorrhizal fungi, associated with L. camara, be used in a subsequent stage of rooting, in order to create a more favorable rhizosphere environment, favoring the performance of the plants.

\section{Literature cited}

Aguiar, C. M.L. \& Zanella, F.C.V. 2005. Estrutura da comunidade de abelhas (Hymenoptera: Apoidea: Apiformis) de uma área na margem do domínio da caatinga (Itatim, BA). Neotrop. Entomol. Londrina, v. 34, n. 1, pp. 15-24.

Augé, M., Stodola, A.J.W., Tims, J.E. \& Saxton, A.M. 2001. Moisture retention properties of a mycorrhizal soil. Plant and Soil. v. 230, pp. 87-97.

Barreto, F., Sousa, E., Campos, A., Costa, J. \& Rodrigues, F. 2010. Antibacterial activity of Lantana camara Linn and Lantana montevidensis Brig extracts from CaririCeará, Brazil. Journal of Young Pharmacists. v. 2, n. 1, pp. 42-44.
Barrs, H.D. \& Weatherley, P.E. 1962. A re-examination of the relative turgidity tecnique for estimating water deficits in leaves. Australian journal of biological sciences. v. 15, n. 3, pp. 413-428.

Bhakta, D. \& Ganjewala, D. 2009. Effect of leaf positions on total phenolics, flavonoids and proantho-cyanidins content and antioxidant activities in Lantana camara (L). Journal of Scientific Research. v. 1, n. 2, p. 363-369.

Carvalho, P.E.R. 2017. Clima. EMBRAPA - Parque Estação Biológica - PqEB, Brasília. Disponível em http://www.agencia.cnptia.embrapa.br/ gestor/especies_arboreas_brasileiras/arvore/ CONT000fud0kxn802wyiv807nyi6swtriw7o.html.

Coelho, I.R., Cavalcante, U.M.T., Campos, M.A.S. \& Silva, F.S.B. 2012. Uso de fungos micorrízicos arbusculares (FMA) na promoção do crescimento de mudas de pinheira (Annona squamosa L. Annonaceae). Acta Botanica Brasilica 26: 933-937.

Coitinho, R.L.B.C., Oliveira, J.V., Gondim Junior, M. G.C. \& Câmara, C.A.G. 2006. Efeito residual de inseticidas naturais no controle de Sitophilus zeamais Mots. em milho armazenado. Revista Caatinga. v. 19, n. 2, pp. 183-191.

Costa, J.G.M., Sousa, E.O., Rodrigues, F.F.G., Lima, S.G. \& Braz-Filho, R. 2009. Composição química e avaliação das atividades antibacteriana e de toxicidade dos óleos essenciais de Lantana camara L. e Lantana sp. Revista Brasileira de Farmacognosia. v. 19, n. 3, pp. 710-714.

Day, M.D., Wiley, C.J., Playford, J. \& Zalucki, M.P. 2003. Lantana: Current Management, Status and Future Prospects. Australian Centre for International Agricultural Research. v. 5, pp. 1-20.

Duggin, J.A. \& Gentle, C.B. 1998. Experimental evidence on the importance of disturbance intensity for invasion of Lantana camara L. in dry rainforest-open forest ecotones in north-eastern NSW, Australia. Forest Ecology and Management. v. 109, pp. 279-292.

Faganello, L.R., Dranski, J.A.L., Malavasi, U.C. \& Malavasi, M.M. 2015. Efeito dos ácidos indolbutírico e naftalenoacético no enraizamento de estacas semilenhosas de Cordia trichotoma (Vell.) Arrab. ex Steud. Ciência Florestal, Santa Maria, v. 25, n. 4, pp. 863-871, out.-dez.

Gantayet, P.K., Adhikary, S.P., Lenka, K.C. \& Padhy, B. 2014. Allelopathic Impact of Lantana camara on Vegetative Growth and Yield Components of Green Gram (Phaseolus radiatus). International Journal of Current Microbiology and Applied Sciences. v. 3, n. 7, pp. 327-335.

Ghosh, S. \& Sarma, M. 2010. Anti-inflammatory and anticancer compounds isolated from Ventilago madraspatana Gaertn., Rubia cordifolia Linn. and Lantana camara Linn. Journal of Pharmacy and Pharmacology. v. 62, n. 9, pp. 1158-1166.

Gidwani, B.K., Bhargava, S., Rao, S.P., Majoomdar, A., Pawar, D.P. \& Alaspure, R.N. 2009. Analgesic, antiinflammatory and anti-hemorrhoidal activity of aqueous extract of Lantana camara Linn, v. 2, n. 2, Research Journal of Pharmacy and Technology, pp. 378-381. 
Haissig, B.E. \& Davis, T.D. 1994. An historical evaluation of adventitious rooting research to 1993. In: T.D. Davis, B.E. Haissig (eds.). Biology of adventitious root formation. Plenum Publishing Corporation, New York, pp. 275-331.

Hartmann, H.T., Kester, D.E., Davis Jr., F.T. \& Geneve, R.L. 2002. Plant propagation: principles and practices. Prentice Hall, New Jersey.

Hoagland, D.R., Arnon, D.I. 1950. The water culture method for growing plants without soils. California Agricultural Experimental Station, Berkeley.

Jimenez-Arellanes, A., Meckes, M., Ramirez, R., Torres, J. \& Luna-Herrera, J. 2003. Activity against multidrug-resistant Mycobacterium tuberculosis in Mexican plants used to treat respiratory diseases. Phytotherapy Research. v. 17, n. 8, pp. 903-908.

Kalita, S., Kumar, G., Karthik, L. \& Rao, K.V.B. 2011. Phytochemical composition and in vitro hemolytic activity of Lantana camara L. (Verbenaceae) leaves. Pharmacology online. v. 1, pp. 59-67.

Kensa, V.M. 2011. Studies on phytochemical screening and antibacterial activities of Lantana camara Linn. Plant Sciences Feed. v. 1, n. 5, pp. 74-79.

Kirimuhuzya, C., Waako, P., Joloba, M. \& Odyek, O. 2009. The anti-mycobacterial activity of Lantana camara a plant traditionally used to treat symptoms of tuberculosis in South-western Uganda. African Health Sciences. v. 9, n.1, pp. 40-45.

Lichtenthaler, H.K. 1987. Chlorophylls and carotenoids: pigments of photosynthetic biomembranes. Methods in Enzymology 148: 349-382.

Lone, R., Shuab, R., Sharma, V., Kumar, V., Mir, R. \& Kul, K.K. 2015. Effect of arbuscular mycorrhizal fungi on growth and development of potato (Solanum tuberosum) plant. Asian Journal of Crop Science. v. 7, pp. 233-243.

Misra, N., Sharma, M., Raj, K., Dangi, A., Srivastava, S. \& Misra-Bhattacharya, S. 2006. Chemical constituents and antifilarial activity of Lantana camara against human lymphatic filariid Brugia malayi and rodent filariid Acanthocheilonema viteae maintained in rodent hosts. Parasitology Research. v. 100, n. 3, pp. 439-448.

Munir,A.A. 1996. A taxonomic review of Lantana camara L. and L. montevidensis (Spreng.) Briq. (Verbenaceae) in Australia. Journal of the Adelaide Botanical Gardens. v. 17, pp. 1-27.

Ning, J. \& Cumming, J.R. 2001. Arbuscular mycorrhizal fungi alter phosphorus relations of broomsedge (Andropogon virginicus L.) plants. Experimental Botany. v. 52, n. 362, pp. 1883-1891.

Nunes, J.L.S., Souza, P.V.D., Marodin, G.A.B. \& Fachinello, J.C. 2010. Interação entre fungos micorrízicos arbusculares e ácido indolbutírico sobre o desenvolvimento vegetativo de plântulas do porta-enxerto de pessegueiro 'aldrighi'. Ciência e Agrotecnologia, Lavras, v. 34, n. 1, pp. 80-86.

Oliveira, G.L., Figueiredo, L.S., Martins, E.R. \& Costa, C.A. 2008. Enraizamento de estacas de Lippia sidoides Cham. utilizando diferentes tipos de estacas, substratos e concentrações do ácido indolbutírico. Revista Brasileira de Plantas Medicinais, Botucatu, v.10, n. 4, pp. 12-17.
Pio, R., Bastos, D.C., Berti, A.J., Scarpare Filho, J.A., Mourão Filho, F.A.A., Entelmann, F.A., Alves, A.S.R. \& Bettiol Neto, J.E. 2005. Enraizamento de diferentes tipos de estacas de oliveira (Olea europaea L.) utilizando ácido indolbutírico. Ciência e agrotecnologia, Lavras, v. 29, n. 3, pp. 562-567.

Priyanka, N. \& Joshi, P.K. 2013. A review of Lantana camara studies in India. International Journal of Scientific and Research Publications. v. 3, n. 10, pp. 1-11.

Rahmawati, N., Rosmayati, Delvian \& Basyuni, M. 2014. Chlorophyll Content Of Soybean As Affected By Foliar Application Of Ascorbic Acid And Inoculation OfArbuscular Mycorrhizal Fungi In Saline Soil. International Journal of Scientific \& Technology Research. v. 3, n. 7, pp. 127-131.

Raizada, P. \& Raghubanshi, A.S. 2010. Seed germination behaviour of Lantana camara in response to smoke. Tropical Ecology. v. 51, n. 2S, pp. 347-352.

Sahu, A.K. \& Panda, S. 1998. Population dynamics of a few dominant plant species around industrial complexes, in West Bengal, India. The Journal of Bombay Natural History Society. J. v. 95, pp. 15-18.

Sanders, R.W. 1987. Taxonomic significance of chromosome observations in Caribbean species of Lantana (Verbenaceae). American Journal of Botany. v. 74, pp. 914-920.

Scagel, C.F. \& Linderman, R.G. 1998. Influence of ectomycorrhizal fungal inoculation on growth and root IAA concentrations of transplanted conifers. Tree Physiol. v. 18, pp. 739-747.

Silva, F.A.S. 2016. Assistant version 7.6 beta. Campina Grande-PB: Assistance Statistics. 2015. Department of Agricultural Engineering CTRN - Federal University of Campina Grande, Campina Grande. Available in http:// www.assistat.com/index.html (access in 02-XII-2016).

Silva, M.A., Cavalcante, U.M.T., Silva, F.S.B., Soares, S.A.G. \& Maia, L.C. 2004. Crescimento de mudas de maracujazeiro-doce (Passiflora alata Curtis) associadas a fungos micorrízicos arbusculares (Glomeromycota). Acta botanica brasilica 18: 981-985.

Souza, P.V.D., Agustí, M., Abad, M. \& Almela, V. 2000. Desenvolvimento vegetativo e morfologia radicular de citrange carrizo afetado por ácido indolbutírico e micorrizas arbusculares. Ciência Rural, Santa Maria, v. 30 , n. 2 , pp. 249-255.

Venkatachalam, T., Kumar, V.K., Selvi, P.K., Maske, A.O. \& Kumar, N.S. 2011. Physicochemical and preliminary phytochemical studies on the Lantana camara (L.) fruits. International Journal of Pharmacy and Pharmaceutical Sciences. v. 3, n. 1, pp. 52-54.

Washa, W.B.A., Nyomora, A.M.S. \& Lyaruu, H.V.M. 2012. Improving propagation success of $D$. melanoxylon (african blackwood) in Tanzania (II): rooting ability of stem and root cuttings of Dalbergia melanoxylon (african blackwood) in response to rooting media sterilization in Tanzania. Tanzania Journal of Science. v. 38, pp. 43-53.

Watts-Williams, S.J., T.W., Turney, A.F., Patti \& T.R. Cavagnaro. 2014. Uptake of zinc and phosphorus by plants is affected by zinc fertiliser material and arbuscular mycorrhizas. Plant Soil. v. 376, pp. 165-175. 